Meta

Journal des traducteurs

Translators' Journal

\title{
Anthologizing classical Chinese poetry in the twentieth and twenty-first centuries: poetics and ideology
}

\section{Wang Feng et Kelly Washbourne}

Volume 64, numéro 3, décembre 2019

URI : https://id.erudit.org/iderudit/1070535ar

DOI : https://doi.org/10.7202/1070535ar

Aller au sommaire du numéro

\section{Éditeur(s)}

Les Presses de l'Université de Montréal

\section{ISSN}

0026-0452 (imprimé)

1492-1421 (numérique)

Découvrir la revue

Citer cet article

Feng, W. \& Washbourne, K. (2019). Anthologizing classical Chinese poetry in the twentieth and twenty-first centuries: poetics and ideology. Meta, 64(3), 687-707. https://doi.org/10.7202/1070535ar
Résumé de l'article

Cette étude examine la conception d'une anthologie en tant qu'activité de prise de décisions, justifiées par un ensemble de textes et de paratextes qui relèvent de critères de sélection poétiques et idéologiques utilisés par les anthologues. Nous tenterons d'analyser la constitution d'une littérature nationale, fruit de la sélection et de l'omission de textes, et de prouver que l'intertextualité et la systématicité des textes d'une anthologie sont étroitement liées. Nous nous concentrerons de manière extensive sur les décisions et procédures relatives à l'histoire de la traduction, comme, par exemple, comment et pourquoi les anthologues sélectionnent les textes, le format de présentation (monolingue, bilingue, l'utilisation du chinois), la provenance (traduction directe ou indirecte) et le public cible. En explorant les critères de sélection, nous pensons éclaircir le problème complexe de la représentativité. Nous avançons l'idée que la conception d'une anthologie et les choix de redéfinition et de formation du canon apparaissent de manière dialogique, en relation étroite avec plusieurs types de textes précédents qui servent d' « originaux » à la " traduction » de l'anthologue. Notre corpus est composé d'anthologies de poésie chinoise classique d'auteurs multiples qui ont été publiées entre 1890 et nos jours. 


\title{
Anthologizing classical Chinese poetry in the twentieth and twenty-first centuries: poetics and ideology
}

\author{
WANG FENG \\ Yangtze University, Jingzhou, People's Republic of China \\ wangfeng@yangtzeu.edu.cn \\ KELLY WASHBOURNE \\ Kent State University, Kent, United States of America \\ rwashbou@kent.edu
}

\begin{abstract}
RÉSUMÉ
Cette étude examine la conception d'une anthologie en tant qu'activité de prise de décisions, justifiées par un ensemble de textes et de paratextes qui relèvent de critères de sélection poétiques et idéologiques utilisés par les anthologues. Nous tenterons d'analyser la constitution d'une littérature nationale, fruit de la sélection et de l'omission de textes, et de prouver que l'intertextualité et la systématicité des textes d'une anthologie sont étroitement liées. Nous nous concentrerons de manière extensive sur les décisions et procédures relatives à l'histoire de la traduction, comme, par exemple, comment et pourquoi les anthologues sélectionnent les textes, le format de présentation (monolingue, bilingue, l'utilisation du chinois), la provenance (traduction directe ou indirecte) et le public cible. En explorant les critères de sélection, nous pensons éclaircir le problème complexe de la représentativité. Nous avançons l'idée que la conception d'une anthologie et les choix de redéfinition et de formation du canon apparaissent de manière dialogique, en relation étroite avec plusieurs types de textes précédents qui servent d'«originaux» à la «traduction» de l'anthologue. Notre corpus est composé d'anthologies de poésie chinoise classique d'auteurs multiples qui ont été publiées entre 1890 et nos jours.
\end{abstract}

\begin{abstract}
We seek in this study to consider anthologizing as a decision-making activity, marshalling evidence from texts and paratexts reflecting anthologists' poetic and ideological criteria for selection; to analyze the construction of a national literature accomplished through text selection and omission; and to provide evidence of the systematicity and intertextuality of anthologized texts as interrelated ecologies. We will focus largely on translation history decisions and procedures such as selection and the anthologists' rationale; presentation format (monolingual, bilingual, the use of Chinese); provenance (direct or indirect translation); and target audience. In exploring criteria for selection, we intend to shed light on the complex problem of representativeness. We posit that anthologizing and its canon-forming and canon-redefining choices appear dialogically, in conversation with various kinds of previous texts, which serve as a kind of "original" to the anthologist's "translation." Our corpus includes multi-author anthologies of classic Chinese poetry that were published from the 1890 s to the present.
\end{abstract}

\section{RESUMEN}

Este estudio se propone considerar la antologización como una actividad que entraña la toma de decisiones; para tal fin reuniremos evidencias de textos y paratextos que reflejan los criterios de selección tanto poéticos como ideológicos precisados por los antologistas; se busca analizar además las construcciones de una literatura nacional a través de 
la selección u omisión de textos; y poner de manifiesto la sistematicidad e intertextualidad de textos antologizados como ecologías interrelacionadas. Nos centraremos mayormente en las decisiones y procedimientos de la historia de la traducción tales como la selección y el razonamiento de los antologistas; el formato de la presentación (monolingüe, bilingüe, el uso del chino); la procedencia (traducción directa o indirecta); y el público meta. Al explorar los criterios de selección, buscamos aclarar el problema complejo de la representatividad. Planteamos que las elecciones que forman y que redefinen el canon al antologizar aparecen de forma dialógica, conversando con múltiples tipos de textos anteriores que sirven como una especie de 'original' de la 'traducción' del/de la antologista. Nuestro corpus incluye antologías de varios autores de la poesía china clásica editada desde los 1890s hasta la fecha.

\section{MOTS-CLÉS/KEYWORDS/PALABRAS CLAVE}

anthologies de traduction, représentativité, canon, poétique, idéologie translation anthologies, representativeness, canon, poetics, ideology antologías de traducción, representatividad, canon, poética, ideología

\section{Introduction}

Anthologies may be traditional or visionary, descriptive or evaluative, pedagogical or popular. The task of anthologies is to

present what the anthologists consider to be the best or most characteristic texts [...] in a given field, or what they judge to be most useful for a given group of readers; in an attempt to stabilize - or, for that matter, to revolutionize - received ways of behavior or conventional perspectives; in the hope of producing a commodity that sells well. (Essman and Frank 1991: 66)

Creative at its core, anthologizing is an exercise in taste, legal acumen, marketing and even artistic vision, a work in a genre form: Jerome Rothenberg reveals that "I came [...] to think of the anthologies, beginning with Technicians of the Sacred, as large, epical constructions or compositions." As the gateway into their subject, anthologies have the power to entice the newcomer, and indeed are test cases for more anthologies. The anthology, like translations themselves, which stand in relation to other texts, "creates a meaning and value greater than the sum of meanings and values of the individual items taken in isolation" (Frank 1998: 13). ${ }^{2}$ Seruya, D’hulst, et al. (2013: 5) sum up the aims of anthologies thus: pleasure, education, preservation, innovation, protection, ${ }^{3}$ structuring, accessibility, dissemination, subjectivity, and profit. Factors such as patronage and politics intervene as well - "conditions of copyright, available funds, interference from the publisher or political censorship" (Chan 2015: 47) - and indeed non-literary scholars have even gotten involved in the process. The larger historical forces that have shaped anthologies should also be borne in mind, especially with regard to the implied purpose that anthologies may serve with respect to the role of reading and the reader:

By the time of the Restoration, collections, highly miscellaneous in substance and style, had come to celebrate aesthetic variety, thus implicitly granting readers the right to make their own literary judgments. In the early eighteenth century, anthologists evolved a distinct set of values (beginning with "elegance") that placed readers in the role of discriminating consumers of art; a few years later, powerful critics and booksellers provided rankings of authors, enjoining or assuming their readers' assent to a proclaimed critical consensus. (Spacks 1997: 349; reviewing and summarizing Benedict 1996) 
The implications of this argument are considerable: anthological variety, by conscious design or otherwise, responds to the historical impulse to grant autonomy to the reader. The extent to which real choice may be offered, however, depends on the amount of new material (source texts, translations, scholarship) and the degree of cross-sectionality. The mediatedness of the choice means selection, and selection entails partiality, incompleteness, and values imposition. The signifying properties of a given text, moreover, are not fixed inscriptions: can, or does, a single writer stand for other writers, kinds of writing, or an era in general?

The problems of anthologizing parallel the invisible work of the translator. Anthologists find that texts are unavailable or available only in poor translations. Lau (1995), acknowledging translators' right to speak in a voice in translation that sets them apart from other translators, points to something unsuspected by the casual reader - that major poets may be available, but translated by different hands, creating the "multifarious ventriloquism" effect of "different Li Pos under one name" (Lau 1995: 223). He reasons that should the focus be on Li Po's accomplishments, singleperson translations might guide their selections, whereas to showcase the poet's multidimensionality, "a chorus of discordant notes" (Lau 1995: 223) might be the appropriate approach. We can subscribe but cautiously to this distinction, generally, inasmuch as risks may attend a single-translator design. To wit, what if the Li Po that emerges from a given translator has no harmonics whatsoever with the source, or if that particular translator's voice overpowers that of the Chinese master? An off-key note is not less discordant if sung by a soloist. And multiple translators, similarly, may not produce multitudinous sounds merely by being multiple, as all may follow the same muse; they can be selected, however, for the deliberate purpose of variety, within the range of authenticity one perceives to be valid. A related dissonant feature of anthologized texts has been perceived, that of flattening, which often refers to the running together of voices into sameness when translated by a single translator who cannot, or does not take pains to, distinguish them. Chaves (1986b: 11-12) calls this, debatably, an "inevitable" and intractable problem. Anthologies can heighten this flaw.

Anthologies and translations share other features, the first of which we might note is intertextuality, the networks of relations we find, for example, in Stephen Owen's description of how, as an anthologist, he translates on the level of "the whole tradition [...] so that you create families of texts to play off against one another." second is the intergeneric and intrageneric relationships that exist in and between anthologies. The selection of certain poets and their poems, presentation forms, and provenance of anthologies are also influenced by such different factors as the dominant poetics, ideology, translators, publishers, and audiences. In this article, the intergeneric relationship between the translation and the original poem refers to the change of genres in translation when poems are translated into prose, as shown in a few prose translations by Herbert A. Giles. The intrageneric relationship exists when regulated Chinese poems are translated into free English verse, or free Chinese poems are translated into regulated English verses, as regulated verses and free verses are two different poetic forms in the genre of poetry. From the corpus, ${ }^{5}$ we find that before Pound's Cathay (1915), seven of the total anthologies were collections of metrical translations. However, from Pound's Cathay onward, only four anthologies in the corpus have been metrical while 28 (70\%) of the anthologies have been in free 
verse. Only one anthology, Select Chinese Verses (Giles and Waley 1934), is a combination of metrical and free verse. Poetics is one of the most critical factors in evaluating preferences in anthologies.

Anthologies may address both the polysystem's center and periphery, restoring reputations, claiming space for new names, and letting go of overrepresented ones. As Chan (2015: 48, 53) reports, the editors of Sunflower Splendor (Liu and Lo 1975/1990), for instance, accord Han Yu 36 poems to Li Bai's 22, and Bai Juyi is likewise given 22; in Watson's Columbia Book, by contrast, Han Yu has only 8, while Bai Juyi, Han Shan, Du Fu and Li Bai have the most among the major poets of the Tang: 25, 25, 23, and 19 poems, respectively. Chan (2015: 48) suggests choices such as Han Yu in Sunflower are "compensational responses" on the anthologists' part. If a single writer has just been accorded a whole volume of his or her own work, such as David Hinton's The Mountain Poems of Meng Hao-jan (2004), an anthologist may feel that including a large selection from that author may be disproportionate on the whole, that is to say, the anthologist may assume that more exposure would be redundant with what is already competently translated and in circulation. It would not make sense, from this perspective, to fault an anthology for underrepresenting a writer that is already well represented elsewhere. The reverse happens, as well - an author is "discovered" by an anthology's translator, who then develops single-author projects in the anthology's wake. Anthologies may even prompt multi-volume anthologies, second volumes published years later - further poems from a given dynasty, for example. Arthur Waley (1919c) in the introduction to his More Translations (Waley 1919b) establishes a continuity of his project's coverage, using a second anthology to signal a work in progress. In this sense anthologies communicate amongst themselves across both space and time. Select Chinese Verses (Giles and Waley 1934) is an anthology to the second power: a selection of anthologized works from Giles and Waley's earlier anthologies and assembled by the publisher, Commercial Press Limited, Shanghai.

The danger lies in seeing anthologies as passive or transparent reportage. Anthologies and translations are

forms of rewriting. As means of selecting, structuring and transmitting culture nationally or transferring culture internationally, anthologies and collections are evidence of the "prejudice of perception" since they tend to reflect, create and project an image of the best poetry, short story, authors (of a nation or in the world) as well as of the relations between national literatures. [...] The interpretation and evaluation underlying this projected image are either explicitly present in titles, subtitles, blurbs, prefaces, notes, commentaries or postfaces, or implicitly embodied in the selection itself [and thus this genre is of] interest for the study of both the formation of cultural identity and of intercultural relations, the creation, development and circulation of national and international canons.... (Seruya, D’hulst, et al. 2013: 4)

It is the relations between literatures that especially interest us, and the ways they are constructed and projected. Anthologies are "reducing valves" rather than "loudspeakers": they begin from a position of constraint, of limited space. In his analysis of anthologizing Africa, André Lefevere (1992/2017: 93-95), not without cynicism, takes up the premise of limits and characterizes anthologies as market commodities competing for readers and thus painting a picture of anthologies as highly calculated expressions: written by and for privileged outsiders, inoffensive, timed to a relevant 
historical event, and modulated in idiom and politics to best effect. They do so, Lefevere (1992/2017: 4) concludes, in ways that hide their historical contingency, their rewriting.

More than rewriting, anthologizing is a reframing. The gatekeeping function of the anthologist is exercised in these paratexts, but also in what is unwritten or excluded, the preliminary norms of aesthetic, pedagogical, and economic choices. One manifestation of this kind of "prejudiced" intervention, as Seruya, D'hulst, et al. (2013) call this image-making, is quality control. Countries' respective centrality or peripherality affects the criteria for quality of an anthologized text as the norms of the receiving culture shape reception. Bernardo (2013: 108) claims that

in minority language contexts such the Portuguese, translations tend to be accepted as an inevitable expedient required to provide access to foreign authors, and their quality is often disregarded. In contrast, in countries where the translational culture is well-developed, more attention is paid to the selection of translations for an anthology with regard to quality.

This claim may need more substantiating, as the inference cannot be drawn automatically that majority-language contexts such as English have either a "translational culture" or unrestricted access to high-quality translations. Nevertheless, it can be conceded that quality of translations has often been second to availability and expediency. The often-made distinction of "academic" and "literary" values of a translation need nuancing, as one may be a poet-academician or be an academic who produces an aesthetically oriented translation, and so on; this is a cline rather than a binary. Another kind of anthological reframing joins the unfamiliar to the familiar in grafting a transnationality, or at least, for example in the case of the branding of Meng Hao-jan's Mountain Poems or the subsection titled "Landscape Poems" (Yip 1976/1997), a strategy of attempting a convergence with the West's long tradition of nature poetry. The rearrangements of the order of source material that occur in many of these anthologies highlight this phenomenon, as happens in the nature poems in The Jade Mountain: A Chinese Anthology, Being Three Hundred Poems of the T'ang Dynasty 618-906 (Liao 2012: 55), or in the prismatic overlay, the thematic subtitles, Arthur Waley (1937) adds to the Confucian Book of Songs: "Courtship," "Marriage," "Blessings on Gentle Folk," "The Clan Feast," "Dynastic Legends," "Moral Pieces," and so on.

\section{Method}

Both internal and factors of translation history have been theorized:

The two main branches of historical translation research are: external and internal translation history. External translation history focuses on institutional questions such as: Which texts by what authors do we find in an anthology? Who were the translators? When and under what circumstances was the anthology made? The test of exclusion (What countries, authors, works have been omitted from a given anthology? Or the entire corpus?) helps to assess the representativeness of the selection. Questions exploring the arrangement within an anthology (What texts are placed in sequence? What other relations are recognizable between the selected words - between the works of various authors or, if applicable, between works of several literatures?) prepare one's way to questions of internal translation history. (Essman and Frank 1991: 73) 
We will focus on internal and external translation history questions such as selection and rationale; presentation format (monolingual, bilingual, the use of Chinese); translation form (regulated verse, free verse); provenance (direct or indirect translation) and target audience. In exploring criteria for selection, we intend to shed some light on the complex problem of representativeness. We aim to demonstrate anthologizing as a decision-making activity, marshalling evidence from texts and paratexts of anthologists' poetic and ideological criteria for selection; to analyze the construction of a national literature accomplished through text selection and omission; and to provide evidence of the systematicity and intertextuality of anthologized texts as interrelated textual ecologies. We have identified our two main concerns as poetics and ideology.

\section{Corpus selection}

We have selected our corpus to include texts meeting the following criteria: classical Chinese poetry (no prose); ${ }^{6}$ late-nineteenth-century through early twenty-first-century anthologies; published in Asia or Anglo-America (without regard to American, British or Chinese translators); multi-author; and not limited to a single theme such as love poetry. In some cases, the first edition of an anthology with two or more editions was included, though for reasons of space the various iterations were not generally compared. Inclusion of the same anthologist with more than one anthology was sometimes allowed, or even a second volume that is the continuation of the first or where a co-anthologist is involved. ${ }^{7}$ We have selected about two volumes published in each decade (1890s-present).

Any number of variables in design were isolated: selection, organization (thematic, chronological/dynastical, rhetorical, geographical, etc.), extension (number of authors), number of translators, multiple versioning, literal or artistic version(s), rhymed or unrhymed verse. Where relevant we also remark on the absence or presence of a scholarly apparatus or didactics, whether the texts are relay translated, and the use of ancillaries (sound files, musical notation). ${ }^{8}$ We address the rhetorical moves in the introductions as well, including defense of a position (poetological, ideological, spiritual, political or otherwise); defense of criteria for inclusion/exclusion; comparisons to Western poets; and critique of previous anthologies.

\section{Discussion of anthology design}

\subsection{Selection constraints and affordances}

\subsubsection{Literal version versus artistic version: collaborations and their (un)acknowledgement}

Examples from the corpus reveal the common anthology format of multiple versions. Often a gloss is employed in producing an "artistic" translation:

- The Never-ending Wrong (1902), edited by Cranmer-Byng, is based on Giles' prose renderings;

- Lyrics from the Chinese (1913), by Waddell, are largely rewritings of Legge's The Book of Poetry (1876); 
- Fir-Flower Tablets (1919) features a raw version by Ayscough that is then poeticized by Amy Lowell;

- A Further Collection of Chinese Lyrics (MacKintosh and Ayling 1969) was "rendered into verse by Alan Ayling from the translations of the Chinese by Duncan Mackintosh in collaboration with Ch'eng Hsi and T'ung Ping-Cheng" (title page);

- Chinese Poetry: An Anthology of Major Modes and Genres (1976/1997) by Wai-lim Yip contains three versions of each poem (original, annotated, aesthetic);

- An Introduction to Chinese Poetry: From the Canon of Poetry to the Lyrics of the Song Dynasty (2018a) by Michael A. Fuller uses a four-part format: the Chinese text, a literal rendering, a heavily footnoted "technical" version, and a "polished professional translation," or more than one (Fuller 2018b: ix).

These examples, in chronological order, span over one hundred years, showing long continuity in versioning practices. Intermediary texts were not always a crib. In at least one case, the editor was working from artistic prose, even published texts: Cranmer-Byng (1902: 10) credits his versions to Gems of Chinese Literature (Giles 1884a) and The History of Chinese Literature (Giles 1901), and prefaces the collection with a five-page paean dedicated to Giles. Though the title gives no indication of their inclusion, the second half of the book contains Cranmer-Byng's own poems, the only such anthology of translations and originals among the corpus. Some translation processes were improvisationally mixed method, such as that employed in Five T'ang Poets (Young 1990a). Young (1990b: 9) depended on "comparing existing translations, drawing upon scholarly discussions of texts [...], working from literal (character-bycharacter) versions prepared by friends or available in published form" and collaborative translation. The most unusual publishing format is that employed in Sunflower Splendor (Liu and Lo 1975/1990), the editors of which made available a Chinese character supplement called K'uei Yeh Chi (Liu and Lo 1976). One collection, Classical Chinese Literature (Minford and Lau 2000), which does not fit the poetry-only parameters we have set for ourselves, includes an approach that future anthologists may pursue more often: multiple versions of the same poem, even into target languages other than English. The New Directions Anthology (Weinberger 2003a) in fact includes multiple versions, including self-revisions by the translators, and even threads the work of different translators together in consecutive cantos originally written by a single source author. Another such work was A Critical Anthology of Tang Poems and their English Translations (Wang and Ma 2011).

Unusually, Arthur Waley (1919a) includes in his A Hundred and Seventy Chinese Poems six literal versions that had already been rendered in poetry by Giles (1898) in Chinese Poetry in English Verse, doing so "with some hesitation" and calling the selections "too typical to omit" (Waley 1919d: v). Instead of offering a competing poetry rendition, Waley "reverse engineers" the poems so that the reader can compare. He also includes an Anglo-Saxon poem in "semi-translation" on the same page as the poem beginning "Wondrous was the wall-stone" accompanying "The Ruins of Lo-Yang" (Waley 1919a: 86-87). His purpose for this thick description maneuver is to show their similarity in structure and atmospherics. Here the different voices of the anthologist - and why not attribute a voice to the anthologist no less than to the translator? - intervene and mingle with that of the commentator or literary historian, and a bit of the schoolmaster.

Translation process is deserving of remark here as well as translation product. A striking procedure, from an ethical perspective, is that taken by Payne in The White 
Pony (1947a). Translators are named in the Acknowledgements and only at the ends of the individual chapters of the poets they translated. The introductory essay, "Method of Translation," asserts the editor's goals:

The aim throughout was to have translations by skilled Chinese scholars rather than the adaptations that have been made by Western scholars. Chinese scholars were asked to translate the poems they believed they were most fitted to translate on the basis of their experience and scholarship; these were then revised by me and submitted to them, until final agreement was reached. My business was chiefly to be editor and reviser; for my knowledge of Chinese was rarely sufficient to allow me to act as arbiter in translating the delicacies of Chinese poetic speech. (Payne 1947b: xxvii)

These Chinese translators do not appear on the title page, or on Worldcat under the "Responsibility" rubric, only the fact of the poems having been "newly translated." In a post-Venuti translation environment, the semi-invisibility of these Chinese translators can only be described as ideologically motivated. If the process was truly as collaborative as the editor notes, the lack of prominent equal credit here, and thus in Sinological intellectual history, points to an implicit hierarchy and an act of literary extractivism. ${ }^{9}$ Crucially, the Chinese translators in question are not given voice to describe the collaboration from their own point of view.

\subsection{Intertextuality and references}

A seldom-remarked feature of anthologies is that they are often translations of existing anthologies and, in some cases, are compilations made in previous eras. In the Chinese case this is particularly relevant, as some anthologies go back millennia, and are historically important as works in their own right. For example, The Jade Mountain (Bynner 1929, from the literal translations of Kiang Kang-hu) is actually a diachronic translation of a source compiled in 1763. Liao (2012: 54) states: "It is the earliest English translation fully based on Tangshi Sanbai Shou (唐诗三百首) [The Three Hundred Tang Poems], an anthology compiled by Sun Zhu 孙洙 (1711-1778) [...]." Similarly, Pound's The Confucian Odes (1954) is actually a translation of the earliest extant collection of Chinese poetry, the Shih-Ching, 305 songs selected and complied by Confucius, though it may have existed in its known form even before the sage's era (Fang 1954: xii). Hawkes' Ch'u Tz'u: The Songs of the South (1959), entitled The Songs of the South: An Anthology of Ancient Chinese Poems by Qu Yuan and Other Poets in the 1985 edition dates from the second century B.C.E. The maintaining of the original titles of the poems with the English subordinated as a subtitle reveals this documentary translation approach: for example, "Li Sao (On Encountering Sorrow)" ${ }^{10}$ or "Zhao Hun (Summons of the Soul)." ${ }^{\prime 1}$ Strictly, then, this is a text subtype or subgenre we can usefully call an anthology in translation (on the model of literature in translation). While manipulations and interventions of all sorts occur in this subgenre, fundamentally it differs in that the anthologist is working with a fixed form, an anthology by induction rather than deduction, as it were.

Essman and Frank (1991: 71-2) remark that the translator's anthology and the editor's anthology can be distinguished. The anthologist-translator's anthology may be a third option they do not envisage, although Frank (1998) does. This model is everywhere in evidence, such as Chaves (1986a). In the calculus of inclusion, this distinction may matter in that an anthologist-translator is or should be cognizant of 
his or her own predilections and skills, and the purpose expands: from the editor's anthology as "art exhibition" to "exhibition and vehicle of transfer" (Frank 1998: 14); that is, the anthologist-translator shows the canon, but also extends it.

In at least one case we find the selection of translators to be a differential marketing strategy. The celebrity translator is on display in the New Directions Anthology (Weinberger 2003a) - the translators, featured prominently on the title page, are the major poets William Carlos Williams, Ezra Pound, Kenneth Rexroth, Gary Snyder, and important scholar-translator David Hinton. ${ }^{12}$ Placing poet-translators so visibly accentuates the connections of the Chinese sources to their influence on American poetry. Abandoning comprehensiveness, the anthologist states his goal as "a book of poetry that may be read cover to cover; it is not a reference work" (Weinberger 2003b: xxvii).

\subsection{Presentation format}

Monolingual, bilingual, and the use of Chinese are the main formats we find in the corpus. By "use of Chinese," we mean the appearance of Chinese characters excerpted from the source and used for design aesthetics, as keywords, as glosses, the latter two of which are aids to language learners. In other words, in this article, we define monolingual in terms of whether the original Chinese poem appears in the English anthology or not. If there are only a few Chinese characters, the anthology is considered monolingual in the broad sense. In the corpus, 34 of the total 40 anthologies are monolingual, 17 of which have no Chinese characters. In the other 17 anthologies, Chinese characters appear in the "Index to Poets," "Key Terms in the Notes," "Glossary - Index," introduction, preface, bibliography, authors' Chinese names, translators' Chinese names, book titles, poems titles, calligraphies or even a rubbing from a stone inscription. Six anthologies are bilingual with original Chinese poems, two of which are translated by Western translators, but published in the Commercial Press in Shanghai, China. In total, 23 of the 40 anthologies use Chinese characters to exhibit Chinese flavor. Sunflower Splendor (Liu and Lo 1975/1990) even has a companion book in Chinese. With regard to Chinese Poems (Waley 1946a), making "a separate edition with the Chinese text opposite the poems" (Waley 1946b: 5) was considered, but Waley was not offered opportunities.

\subsection{Indirect translations}

Indirect translation is a translation of a translation. Two kinds of indirect translation are: 1) the translation is from a mediating language which is different from the source language and the target language, and 2) the translation is based on one or more than one version in the target language, which is equivalent to rewriting, or intralingual translation (Wang 2015: 14). Translations from published intermediary texts appear in the corpus. Most notably, Chinese Lyrics from the Book of Jade by James Whitall (1918) was derived from Judith Gautier's (1845-1917) Le Livre de Jade (1867). Kenneth Rexroth (1956b: xi) in his compilation One Hundred Poems (Rexroth 1956a) consulted German and French translations, English prose versions, and literal versions in addition to originals. Such indirect translations belong to the first category, while CranmerByng's indirect translations are examples of the second type when he renders The 
Never-ending Wrong and Other Renderings of the Chinese (1902) and A Lute of Jade: Being Selections from the Classical Poets of China (1909a) from the English prose translation of Herbert A. Giles. Cathay by Ezra Pound, based on the notes of the late Ernest Fenollosa, also belongs to the second category. Sometimes, indirect translation has been and may be necessary or even the only choice, for certain translators. However, there are many arguments against indirect translation (Wang 2015: 15). Firstly, the translated work will inevitably be marked with the characteristics of the interlanguage and interculture. Second, it is not convenient to do a comparative study between the source text and the target text; thus, mistranslation, additional translation and omission are more likely to occur in indirect translation. Thirdly, indirect translation is theoretically more likely to ignore the linguistic and cultural characteristics of the source language and culture. And finally, indirect translation may be practiced imperceptibly, mingling marked and unmarked indirect translations, or overt and covert forms.

\section{Discussion: rhetorical moves in prefaces}

\subsection{Criteria for inclusion (I): ideology}

Defenses of adjustments to the classical Chinese poetry canon take various forms. David Hinton's translator's note connects text selection to a worldview of resistance against contemporary poetry that ignores our physicality, and by extension, reclaims the ethical imperatives that go with living in "the physical realm of natural process":

Although it means ignoring the hundreds of noteworthy poets whose work makes up the evolving texture of China's poetic tradition [...] this anthology presents Chinese poetry as a tradition of major poets whose poetics created new possibilities for the art, which is to say, gave new dimensions to the Taoist/Ch'an unity of cosmos, consciousness, and language. In this modern age, vast environmental destruction has been sanctioned by people's assumption that they are spirits residing only temporarily here in a merely physical world created expressly for their use and benefit. This makes the Taoist/Ch'an worldview increasingly compelling as an alternative vision in which humankind belongs wholly to the physical realm of natural process. [This anthology] addresses every aspect of human experience, revealing how it is actually lived with that alternative perspective - not in a monastery but in the always compromised texture of our daily lives. (Hinton 2008b: xxvi)

Barnstone for his part openly asserts his motivation as breaking with tradition and "proportionality":

We have... attempted to adjust the canon... to shine a spotlight on fine poets whose work is often overlooked, and especially to make room for the poems of Chinese women. [...] Perhaps one could argue that we are skewing the canon by including a fifth of the fifty extant poems of the great woman poet Li Qingzhao, while including only one thousandth of the poems of Lu You, who wrote more than ten thousand poems. However, our goal is not to be merely representative [...]. (Barnstone 2005b: xxxv-xxxvi)

"Merely representative" thus is posited as the uncritical pole of possible approaches for the anthologist, and promotion - necessarily "biased" - the opposite or interventionist pole. Indeed, what could "representative" truly claim, at all events? Including 
only the most highly regarded, the most-anthologized writers would merely reproduce what has been done, which no book sets out as a goal, including only those who are consecrated in China might overlook factors related to translation, as well as Western sensibilities. This tension plays out through the texts in our corpus. Xie (1999: 6), for example, reading Waley's greater sampling of Po Chü-i, relative to Pound's preferences, as Waley having "tacitly criticized and challenged Pound's taste in translating almost solely from Li Po by disputing Li Po's own standing in the Chinese poetic tradition." Thus, it is not enough to invoke representativeness; we must answer an implicit question: representative for whom? In the T'ang canon alone there are more than 50,000 poems - who can distill these into a single work? As Watson (1984: 13) pointed out, the usual aim of an anthology is to "give a representative selection" of Chinese poetry. To achieve this goal, it is essential to include the most important poets in the Chinese poetic canon such as Qu Yuan, Tao Yuanming, Li Bai, Du Fu, Wang Wei, Bai Juyi, and Li Qingzhao. For example, even though Han Shan might be still popular among certain Americans, as mentioned in our conclusion, he will not be likely to be justifiably included in an anthology of Chinese poetry, because he is not listed in traditional Chinese poetic canon. Additionally, we can argue, as does Kittel (1995: xiv), that anthologies should be studied in conjunction with national histories of literature and, in particular, with marginalized literatures (Rabadé 2016: 389). In part this literary-historical lens can show how inclusion or exclusion of authors in anthologies may be based on current, and changing, tastes.

It is likely, too, that anthologists have drawn upon and sought to further political goodwill, an asset transcending the scholarly/popular divide. Fletcher's Gems of Chinese Verse (1919a), for example, advertises the value of peace underlying the poems as a whole (Fletcher 1919b: ii), and A Lute of Jade (Cranmer-Byng 1909a), an anthology from the WWI era, is prefaced with a cosmopolitan overture, a wish that

these books shall be the ambassadors of good-will and understanding between East and West - the old world of Thought and the new of Action. [...] They are confident that a deeper knowledge of the great ideals and lofty philosophy of Oriental thought may help to a revival of that true spirit of Charity which neither despises nor fears the nations of another creed and colour. (Cranmer-Byng 1909b: 8)

This rhetoric may reflect war-weariness at the same time it subtly relegates China to "the old world of Thought," exiling it from the present as it arrogates for the West the implicitly superior position of protagonist of history ("Action"). This was still before China, eventually an ally, declared war on Germany in 1917. A full century later, then, we are rightly surprised by the ethnocentrism of the 1969 editorial introduction to Ayling and Mackintosh, written by John Smith, poet, critic and editor of The Poetry Review:

[Duncan Mackintosh] has rescued [the chosen poets] from the false world of our previous conceptions. We see them not as strange beings from a world more alien than Venus or Mars, but human beings little removed from ourselves, exhibiting similar qualities of love, anger, passion, ribaldry, wit [...] dealing with problems that are permanent in human nature. (Smith 1969: x)

That is, by showing their commonalities with the ancients, they find their assumptions challenged. The question may well be why in 1969 - not even 1869 anyone imagined another people as "strange beings" from another planet, hyper- 
bolically or not, or as having anything but human emotions. ${ }^{13}$ It would be hard to find a stronger yet more subtle example of Orientalist "othering."

Ideology has been described as "that grillwork of form, convention, and belief which orders our actions” (Lefevere 1992/2017: 13, quoting Jameson 1974: 107), beyond politics. Choices of text naturally bear ideological imprint. Translational choices, microtextual shifts, are of course another ideological front. Chan blames Giles' approach in his 1884 text Gems of Chinese Literature, for instance, for "cushioning the general public against foreign cultural content" (Chan 2017: 39). Giles removes "allusions which for the most part would be shorn of all meaning" and "long strings of unpronounceable names” (Giles 1884b: v, quoted in Chan 2017: 39-40).

\subsection{Criteria for inclusion (II): representativeness over quality}

Low-quality inclusions in anthologies are often justified, or at least remarked, in paratexts as the price of inclusiveness. Smith's (1969: $\mathrm{x}$ ) foreword to Ayling and Mackintosh's Further Collection, for example, reasons that "there are included certain poems which are not, in themselves particularly original or inspired but which are indicative of the personality of the poet concerned, or demonstrate some aspects of the contemporary society." The goal of representativeness almost begins to seem to be in opposition to the aesthetic goal of uniformly excellent work, especially when we read reviews such as the following, of Chaves' The Columbia Book of Later Chinese Poetry (1986a):

That the quality of the translations here is far more uneven than in any previous work by Chaves simply attests that the translator has occasionally subordinated his remarkable literary talents to the needs of [students and scholars], choosing to show mediocre and even bad poets, and to clearly demonstrate the range as well as the clearest triumphs (the reach as well as the grasp) of the better poets. [However,] a representative anthology is achieved, and the parts are justified by the whole. (Seaton 1985: 196)

The reviewer makes the valid point that without such scope, such a democratic approach to anthologizing, certain poets might never see the light of day outside of Chinese. Yet others, citing the constraint of lack of space, argue for more discriminating choices. Jenyns (1940b: 20-21) reasons in his foreword to Selections from the Three Hundred Poems of the T'ang Dynasty (Jenyns 1940a) that his scant 116 pages of verse from this original eighteenth-century T'ang source of 298 poems was inevitable to avoid monotony and mediocrity, and defends the brevity on the limitations of space in the book series. Thus, anthologies are expected by many readers to provide a picture of the whole, readers who may be ill served by Hinton's conception, noted above, of the anthology as a "tradition of major poets."

Moreover, anthological selection may be based on reasons of reparation, tradition, innovation or pedagogics. Arthur Waley tells us in his "Preliminary Note" to A Hundred Seventy Poems (1919a):

I have tried to avoid poems which have been translated before. A hundred and forty of those I have chosen have not been translated by anyone else. The remaining thirty odd I have included in many cases because the previous versions were full of mistakes. (Waley 1919d: v)

Bernardo (2013: 108) references the polysystem, which regulates what is "prescribed, prohibited, permitted and tolerated." Design constraints include "copyright, aesthetic 
value, availability, temporal context of the translation, a foreignizing vs. domesticating translation strategy, political background, the translator's personal taste and status, [and] easy comprehension by the target reader" (Bernardo 2013: 108). Another pragmatic issue is the fit or affinity between the editor and the potential writer, which can include issues of perceived translatability. Chaves (1986b: 11), for example, admits to omitting major figures for lack of an effective approach to translating them (he is the sole editor and translator), although one may fairly wonder why specialists could not be brought in to supplement such a lacuna. Unfinished translations are included in The White Pony (Payne 1947a) on account of Li Ho's being "almost impossible to translate" (Ho 1947: 295-296). Waley (1946b) has translated ten times more poems by Bai Juyi than by any other writer because he thinks that Bai Juyi is "the most translatable of the major Chinese poets" (Waley 1946b: 5). Tradition, or even "thematic correctness," Yeh's (1995: 278) term for Chinese nationalism in selection criteria, accounts for some inclusions; above, we saw Waley lament that certain poems were "too typical to omit" (Waley 1919d: v).

\subsection{Audience}

Selection and audience are inextricable factors. Miao (1978: 736) characterizes The Flowering Plum and the Palace Lady (Frankel 1976) as reminiscent of the "shih-hua (comments on poetry) and pi-chi (informal notes) traditions," although Chaves (1978: 172-173) finds it misses both popular and scholarly audiences. The anthology form is sometimes another kind of text in disguise: a commentary or study, one that is often highly idiosyncratic, and for that reason some readers and critics are unprepared readers. Some anthologies take a "poem itself" approach and offer very little context, relying on the aesthetic force of the work to guide the reader. Old Friend from Far Away (Kwock and McHugh 1980), for example, has no introduction and bare minimum poet biographies, only an acknowledgement and a postface reprinted from 1968 (giving some context to its Beat-inflected musings), a translators' dialogue on poetry translation, playfully dedicated to "Chairman Wen Ch'ang," Chinese god of literature. We cannot overlook such works in our considerations here inasmuch as independent books (the press was an imprint of Farrar, Straus, and Giroux) did not tend to use scholarly apparatuses and produced readerly translations. This means that rather than cohesiveness with the anthology tradition, such works follow the lead of the series aesthetic, and perhaps more generally, that of the small press, which eschews didacticism and heavily annotated works.

Popular and academic anthologists alike use a rhetoric aware of competing approaches. Rexroth makes no claims to scholarship: "Just some poems" (Rexroth 1956b: xii). And A Garden of Peonies (Hart 1938a) disarms the reader of any expectations of rigorous selection criteria or fear of scholarship: "simply the garnerings of many hours of pleasant wanderings through the highways and byways of my library of Chinese verse" (Hart 1938b: xi). According to Wang (2014: 72), a literary work is included in the canon based on the literary market, critical response, authoritative anthologizing and university curriculum. Thus, poems chosen for their personal meaning, or appearing with a presentation that eschews academic pretense, have few direct access points into the canon-formation of this body or any of literature. Yet popular works can increase dissemination and acceptance into the canon of cultural 
capital by gaining cachet through non-academic routes such as these, that is, a popular anthology may increase the likelihood of future prestige and critical favor, as measured by Wang's four criteria. The case of Rexroth's (1956a) One Hundred Poems suggests the movement from popular to academic is a path to the canon. Chan (2017: 70) makes a perceptive leap in her reading of Eoyang's (1993: 68) observation that latter-day translators address three readerships: Anglophone readers, learners of Chinese, and, finally, English-speaking Chinese readers. She concludes that anthologist-translators are not the only authorities on selection and translation as they once were (Chan 2017: 70). By implication, anthologies in some critics' estimation were never, or not in their earliest iterations at all events, the open invitation to reader autonomy we saw theorized above.

It is not only the scholarly apparatus that anthologists use to mark differences in approach, but the poeticity of the renderings. Leaving aside our own judgments of his renditions, we will consider Young's justification of his work, which stands out for its distinction between artistry and accuracy. He openly advertises the fact that no previously untranslated poems appear in his anthology and that previous translators had better command of Chinese than he does. His justification for retranslating is to attempt effective poems in the target language, and "[n]o amount of scholarship and erudition can substitute for that" (Young 1990b: 10). He derides Sunflower Splendor (Liu and Lo 1975/1990) as "deplorable" (Young 1990b: 10) poetry, despite its accuracy, and strives in his own versions for more "limber" (Young 1990b: 11) versions to supplement the wooden ones he claims appear in Sunflower. Young's (1990b: 11) primary allegiance is to the readers without dispensing with critical accuracy. Some works interpret their role as mediating for the reader, dispensing with reader autonomy and making explicit connections for them, that is

Fir-Flower Tablets might target at readers who might favour books which had been "digested" by translators, editors, or publishers. The readers might expect that the book they chose gave a sense of contemporariness with which they could identify, for example, the vogue of Imagism. (Liao 2012: 54)

And yet scholarly convention is a dimension in which anthologies have met resistance, for example in the lack of a pronunciation guide. McCraw's (2010) review of How to Read Chinese Poetry is emblematic also in this respect. The reviewer rejects the anthologist's goals as too idealistic for beginners (the text cannot, he argues, give access to the source Chinese), and he takes issue particularly with the publication's reliance on Chinese texts and Romanizations (McCraw 2010: 22-23).

\section{Conclusion}

We have considered a small but important corpus of anthologies and analyzed constructions of an era of Chinese poetry accomplished through text selection, and noted broad trends in anthologized texts as a reactive and proactive genre, shaping and reflecting priorities, and even biases, of their times. Lefevere's (1992/2017: 92) observation that literary history "[enlists] the support of those writers it canonizes for a certain ideology, a certain poetics, or both" is borne out by our brief tour. Some of the various tensions involved in anthologists' objectives and reception were surveyed. Internal and external translation history decisions and procedures, presentation format, provenance (direct or indirect translation), and target audience revealed just 
some of the problems of representativeness that characterize the anthologizing project, the complexity of which has led us to a dizzying axiom: no two texts in an anthology need have been chosen for the same reasons, or translated with the same goals. Our observations here may be taken as some first steps on the classic Chinese poetry anthology as a strategic and complex system of ideology and poetic choices made by active agents in discrete historical moments, and often with full awareness of the texts that precede and co-circulate with their own productions. We have identified a translation anthologist's "voice," which manifests in new critical, historical and aesthetic framings. Some of the evidence we have gathered is quantitative, showing patterns of format, inclusions and exclusions, and other editorial-level choices. Some has been qualitative, largely where we draw on the rhetorical constructions found in paratexts and reviews to show a range of ideological stances.

Future directions might consider how anthologies are actually read, including reception studies of whether readers read them selectively or wholly. In fact, we often find that multiple overlapping and even often competing goals - documentary accuracy, aesthetic mastery, inclusive selection - may be present in many of the texts, and that a balance often proves elusive. There may even be a "re-anthologization hypothesis" to explore: the idea that earlier anthologies are intended for more naive readers and that they are more visibly ideological in the vision of the whole they seek to portray. The proposition, still untested, might be that anthologies become more "disciplined," more accountable, over time and build on the beginner's anthology toward the more advanced anthology. These are different conveyances serving different goals and audiences, and yet little distinguishes them in the marketplace, sometimes to the frustration of readers.

The issue of how classical Chinese poets are represented over the surveyed centuries also turns up attitudes that shape the selection and framing of texts. We might ask harder questions in future studies about who is left out and why, and who makes the decisions, who is anthologizing, and who is publishing. Patterns of relatively marginal poets in China, such as Han Shan, may become marketed much more aggressively in part through collections or anthologies appearing in the West, a phenomenon worthy of study in its connections to translator intervention and "functionalist" goals, such as creating from him for the West a Zen precursor and icon of reclusivity. The issue of co-textual signifiers, such as illustrations, titles, and marketing language, and how these contribute to an image of a literary tradition, needs further exploration in the case of Chinese poetry anthologies. And as suggested above, literary-historical criteria for inclusion such as authors selected or deselected for anthologies based on current taste and theoretical climate might be explored. For the anthology to fully decolonize itself as a form, discussion of a century or more of framings and their inheritances can only lead us to better knowledge of ourselves, inasmuch as one becomes what one notices, values, and preserves.

\section{ACKNOWLEDGEMENTS}

This work was supported by the Chinese Ministry of Education's Humanities and Social Sciences 2015 Youth Fund under Grant [15YJC740078] and by the National Social Science Fund of China under Grant [Key Project 17AZD040]. 


\section{NOTES}

1. Suzor, Sarah (2009): Poet and Polemicist: an interview with Jerome Rothenberg. Rain Taxi. Consulted on 7 July 2018, <http://www.raintaxi.com/poet-and-polemicist-an-interview-withjerome-rothenberg/>.

2. Seruya, D'hulst, et al. have focused perhaps too much on the actual use of the word anthology in the title of a collection. The anthology that does not market itself as such may still be an anthology. H. M. Enzensberger's Museum der Modernen Poesie (1960) called itself a museum. Similarly, Sunflower Splendor, as ambitious an anthology in scope as one is likely to find, avoids the term altogether. Wai-Lim Yip's Chinese Poetry: Major Modes and Genres (1976) becomes Chinese Poetry: An Anthology of Major Modes and Genres in the second edition (1997), even though it was already an anthology. Bernardo (2013: 109) lamented the difficulty in finding anthologies due to the tendency of publishers to name collections with a figurative phrase, such as a line of verse, that does not include anthology. Moreover, the semantic distinction between collection and anthology, namely that "a collection is 'a gathering of new or mostly new writing,' whereas an anthology is 'a gathering of previously published, or mostly previously published, work”' (Di Leo 2004: 4), is not valid for many of the anthologies surveyed here.

3. "[L]iterary production of minorities tends to become available and known by means of anthologies, since it seldom reaches autonomous publication or a wide reading public (Seruya 2013: 3).

4. Quoted in SHAw, Jonathan S. (1998): Anthologizing as a Radical Act. Harvard Magazine. Consulted on 30 September 2018, <https://harvardmagazine.com/1998/07/norton.html>.

5. The corpus is composed of 40 anthologies. See Appendix 1. For the references to the paratexts, see Appendix 2.

6. Texts including contemporary poetry were included provided they also contained ancient poetry.

7. Anthologists of Chinese verse in some cases have two or more, even three or more, anthologies; in the latter case, for example, consider Henry Hart: A Chinese Market Lyrics from the Chinese in English Verse (1931), A Hundred Names (1933), A Garden of Peonies (1938a), and The Charcoal Burner and Other Poems (1974).

8. At least three collections surveyed have a musical component. How to Read Chinese Poetry (Cai 2008) is a multimodal anthology, featuring sound recordings. See CAI, Zong-qi (2008): Audio Files for How to Read Chinese Poetry. Columbia University Press. Consulted on 13 August 2019, <https:// cup.columbia.edu/extras/sound-files-for-how-to-read-chinese-poetry $>$. In the appendices of Mackintosh and Ayling (1969) are musical notations for the poems. And Weinberger (2003b: xxiii) reminds us that Pound's Odes were intended as a songbook.

9. Robert Payne chaired the PEN Translation Committee until 1976, whereupon he left to co-found the Translation Center at Columbia. See Special Collections and University Archives (Last update: 10 July 2017): Biography. Robert Payne Collection. Stony Brook: Stony Brook University. Consulted 3 May 2019, <https://www.stonybrook.edu/commcms/libspecial/collections/manuscripts/payne/biography.html >. In his many contributions to translation, it is all the more troubling and incongruous to see no translator copyright or prominent credit given on The White Pony.

10. Qu, Yuan (3 ${ }^{\text {rd }}$ c. BCE/1959): Li Sao (On Encountering Sorrow). In: David Hawkes, ed. Ch'u Tz'u: Songs of the South. Oxford: Clarendon Press, 21-34.

11. Song, Yu (3 ${ }^{\text {rd }}$ c. BCE/1959): Zhao Hun (Summons of the Soul). In: David Hawkes, ed. Ch'u Tz'u: Songs of the South. Oxford: Clarendon Press, 101-108.

12. The reader may rightly wonder whether the celebrity translator or "rockstar" translator, as it has been theorized, has the potential to place strong poets in competition with their sources. Certainly, this is a hypothesis to be tested, but as a rule a translator's skill does not diminish perforce in proportion to his or her notoriety.

13. Lest the reader think such a comparison anomalous, Wolfe in Arthur Waley's Poems from the Chinese writes, "Mr. Waley, translating not merely from one language into another, but almost from one planet into another [...]" (Wolfe 1920: iii; our emphasis). It would be easy to collect many such examples from the century's anthologies. 


\section{REFERENCES}

Benedict, Barbara M. (1996): Making the Modern Reader: Cultural Mediation in Early Modern Literary Anthologies. Princeton: Princeton University Press.

Bernardo, Ana Maria (2013): Poetry anthologies as Weltliteratur projects. In: Teresa Seruya, Lieven D'Huslt, Alexandra Assis RosA, et al., eds. Translation in Anthologies and Collections (19th and 20th Centuries). Amsterdam/Philadelphia: John Benjamins.

Chan, Chi Man Cecilia (2017): Cultural Representation and Translation: Chinese and English Anthologies of Tang Poetry. Doctoral dissertation, unpublished. Hong Kong: Lingnan University.

CHAN, Red (2015): Intellectual Intervention and English Anthologies of Chinese Literature of the 1980s. Asia Pacific Translation and Intercultural Studies. 2(1):46-56.

Chaves, Jonathan (1978): Review of The Flowering Plum and the Palace Lady: Interpretations of Chinese Poetry by Hans H. Frankel [1976, New Haven/London: Yale University Press]. Modern Asian Studies. 12(1):172-174

Di Leo, Jeffrey R. (2004): Analyzing Anthologies. In: Jeffrey R. Di Leo, ed. On Anthologies: Politics and Pedagogy. Lincoln/London: University of Nebraska Press, 1-27.

Essman, Helga and Frank, Armin Paul (1991): Translation Anthologies: An Invitation to the Curious and a Case Study. Target. 3(1):65-69.

Frank, Armin Paul (1998): Anthologies of Translation. In: Mona BAKer, ed. Encyclopedia of Translation Studies. London/New York: Routledge, 13-16.

Giles, Herbert (1901): A History of Chinese Literature. London: William Heinemann.

Ho, Chih-Yuan (1947): Li Ho. In: Robert Payne, ed. The White Pony: An Anthology Of Chinese Poetry From The Earliest Times To The Present Day, Newly Translated. New York: The John Day Company, 293-297.

Jameson, Fredric (1974): The Prison House of Language. Princeton: Princeton University Press. Kittel, Harald (1995): Anthologies of Literature in Translation: An Introduction to Incipient Research. In: Harald KitTeL, ed. International Anthologies of Literature in Translation. Berlin: Erich Schmidt, ix-xxvii.

LaU, Joseph S. M. (1995): More Than Putting Things Together: The Anthologizing of Chinese Literature in Translation. In: Eugene EoyANG and Yao-fu Lin, eds. Translating Chinese Literature. Bloomington/Indianapolis: Indiana University Press, 221-230.

Lefevere, André (1992/2017): Translation, Rewriting and the Manipulation of Literary Fame. London/New York: Routledge.

Liao, Chia-hui (2012): The Reception and Translation of Classical Chinese Poetry in English. NCUE Journal of Humanities. 6(2):47-64.

McCraw, David (2010): Review of How to Read Chinese Poetry: A Guided Anthology by Zong-qi CAI [2008, New York: Columbia University Press]. China Review International. 17(1):22-43.

Miao, Ronald (1978): Review of The Flowering Plum and the Palace Lady: Interpretations of Chinese Poetry by Hans H. Frankel [1976, New Haven/London: Yale University Press]. The Journal of Asian Studies. 37(4):736-738.

Rabadé, María (2016): The Anthology as Instrument of Mediation. In: César Domínguez, Anxo Abuín González and Ellen SAPega, eds. A Comparative History of Literatures in the Iberian Peninsula. Vol. 2. Amsterdam/Philadelphia: John Benjamins, 381-399.

Seaton, Jerome P. (1985): Review of The Columbia Book of Later Chinese Poetry by Jonathan Chaves [1986, New York: Columbia University Press]. Chinese Literature: Essays, Articles, Reviews (CLEAR). 7(1/2):196-198.

Seruya, Teresa (2013): Anthologies and translation. In: Yves Gambier and Luc van Doorslaer, eds. Handbook of Translation Studies. Vol. 4. Amsterdam/Philadelphia: John Benjamins, $1-6$.

Seruya, Teresa, D'Hulst, Lieven, Rosa, Alexandra Assis, et al. (2013): Introduction: Translation Anthologies and Collections: An Overview and Some Prospects. In: Teresa SeruyA, Lieven 
D'Hulst, Alexandra Assis Rosa, et al. eds. Translation in Anthologies and Collections (19th and 20th Centuries). Amsterdam/Philadelphia: Benjamins, 1-14.

Spacks, Patricia Meyer (1997): Review of Making the Modern Reader: Cultural Mediation in Early Modern Literary Anthologies by Barbara M. Benedict. [1996, Princeton: Princeton University Press] and of The True Story of the Novel by Margaret Anne Doody. [1996, New Brunswick: Rutgers University Press]. Eighteenth-Century Fiction. 9(3):349-353.

Wang, Feng (2015): A Comprehensive Study on the English Translation of Classical Tang Poetry. Beijing: China Social Sciences Press.

WANG, Ning (2014): Translating Chinese Literature: Decanonization and Recanonization. In: Ming Dong Gu and Rainer Schulte, eds. Translating China for Western Readers. Albany: SUNY Press, 71-88.

XIE, Ming (1999): Ezra Pound and the Appropriation of Chinese Poetry: Cathay, Translation, and Imagism. New York: Garland.

YeH, Michelle (1995): On English Translation of Modern Chinese Poetry: A Critical Survey. In: Eugene EoyANG and Yao-fu Lin, eds. Translating Chinese Literature. Bloomington: Indiana University Press, 275-291.

\section{APPENDIX}

\section{Appendix 1: Corpus of anthologies (chronological order)}

Giles, Herbert, ed. (1884a): Gems of Chinese Literature. (Translated from Chinese by Herbert GILEs) London/Shanghai: Bernard Quaritch/Kelly \& Walsh.

Allen, C. F. Romilly, ed. (1891): The Book of Chinese Poetry. (Translated from Chinese by C. F. Romilly Allen) London: Kegan Paul, Trench, Trübner \& Co.

Giles, Herbert, ed. (1898): Chinese Poetry in English Verse. (Translated from Chinese by Herbert GiLes) London/Shanghai: Bernard Quaritch/Kelly \& Walsh, Ld.

Cranmer-Byng, Launcelot Alfred, ed. (1902): The Never-ending Wrong and Other Renderings of the Chinese from the Prose Translations of Professor Herbert A. Giles. (Translated from Chinese by Launcelot Alfred CrAnMer-Byng) London: Grant Richards.

Cranmer-Byng, Launcelot Alfred, ed. (1909a): A Lute of Jade: Being Selections from the Classical Poets of China. (Translated from Chinese by Launcelot Alfred CRANMER-Byng) London: John Murray.

Budd, Charles, ed. (1911/1912): A Few Famous Chinese Poems/Chinese Poems. (Translated from Chinese by Charles BuDd) Shanghai: Kelly \& Walsh.

WADDELL, Helen, ed. (1913): Lyrics from the Chinese. (Translated from Chinese by Helen WADDELL) Boston/New York: Houghton Mifflin Company.

Pound, Ezra, ed. (1915): Cathay. (Translated from Chinese by Ezra Pound) London: Elkins Mathews.

WALEy, Arthur, ed. (1916): Chinese Poems. (Translated from Chinese by Arthur WALEy) London: George Allen and Unwin.

Whitall, James, ed. (1918): Chinese Lyrics, from The Book of Jade. (Translated from the French of Judith Gautier by James Whitall) New York: B. W. Huebsch.

Fletcher, William J. B., ed. (1919a): Gems of Chinese Verse. (Translated from Chinese by William J. B Fletcher) Shanghai: The Commercial Press.

Waley, Arthur, ed. (1919a): A Hundred and Seventy Chinese Poems. (Translated from Chinese by Arthur Waley) New York: Alfred A. Knopf.

Waley, Arthur, ed. (1919b): More Translations from the Chinese. (Translated from Chinese by Arthur Waley) New York: Alfred A. Knopf.

Ayscough, Florence and Lowell, Amy, eds. (1919): Fir-Flower Tablets: Poems from the Chinese. (Translated from Chinese by Florence Ayscough and Amy Lowell) Boston/New York: Houghton Mifflin Company.

WALEy, Arthur, ed. (1920): Poems from the Chinese. (Translated from Chinese by Arthur WALEy) London: E. Benn. 
Bynner, Witter, ed. (1929): The Jade Mountain: A Chinese Anthology, Being Three Hundred Poems of the T'ang Dynasty, 618-906. (Translated from the Chinese texts of Kiang Kang-hu by Witter Bynner) New York: Alfred A. Knopf.

Giles, Herbert and Waley, Arthur, eds. (1934): Select Chinese Verses. (Translated from Chinese by Herbert Giles and Arthur Waley) Shanghai: Commercial Press.

Waley, Arthur, ed. (1937): The Book of Songs. (Translated from Chinese by Arthur Waley) London: George Allen \& Unwin.

Hart, Henry H., ed. (1938a): A Garden of Peonies: Translations of Chinese Poems into English Verse. (Translated from Chinese by Henry H. HART) Stanford/London: Stanford University/ Oxford University Press.

Jenyns, Soame, ed. (1940a): Selections from the Three Hundred Poems of the Tang Dynasty. (Translated from Chinese by Soame JenYns) London: John Murray.

Payne, Robert, ed. (1947a): The White Pony: An Anthology of Chinese Poetry from the Earliest Times To the Present Day. (Translated from Chinese by Robert Payne, Yu-ting Shen, Yehtzu Yang, et al.) New York: The John Day Company.

Pound, Ezra, ed. (1954): The Confucian Odes: The Classic Anthology Defined by Confucius. (Translated from Chinese by Ezra Pound) Cambridge: Harvard University Press.

Rexroth, Kenneth, ed. (1956a): One Hundred Poems from the Chinese. (Translated from Chinese by Kenneth Rexroth) New York: New Directions.

MacKintosh, Duncan and Ayling, Alan, eds. (1965): A Collection of Chinese Lyrics. (Translated from Chinese by Duncan MacKintosh and rendered into verse by Alan Ayling) London/ New York: Routledge/Kegan Paul.

MacKintosh, Duncan and Ayling, Alan, eds. (1969): A Further Collection of Chinese Lyrics and Other Poems. (Translated from Chinese by Duncan MacKintosh, in collaboration with Hsi CH'Eng and Ping-cheng T'Ung, and rendered into verse by Alan AyLING) London/ New York: Routledge/Kegan Paul.

Watson, Burton, ed. (1971): Chinese Lyricism. (Translated from Chinese by Burton Watson) New York/London: Columbia University Press.

Frankel, Hans H., ed. (1976): The Flowering Plum and the Palace Lady: Interpretations of Chinese Poetry. (Translated from Chinese by Hans H. Frankel) New York/London: Yale University Press.

Liu, Wu-chi and Lo, Irving Yucheng, eds. (1975/1990): Sunflower Splendor: Three Thousand Years of Chinese Poetry. (Translated from Chinese by Wu-chi Liu, Irving Yucheng Lo, Burton Watson, et al.) New York: Anchor Press.

YIP, Wai-lim, ed. (1976/1997): Chinese Poetry: An Anthology of Major Modes and Genres. (Translated from Chinese by Wai-lim YIP) Durham/London: Duke University Press.

Kwock, Chan Hoon and McHugh, Vincent, eds. (1980): Old friend from Far Away: 150 Chinese Poems from the Great Dynasties. (Translated from Chinese by Chan Hoon Kwock and Vincent McHugh) San Francisco: North Point Press.

Watson, Burton, ed. (1984): The Columbia Book of Chinese Poetry: From Early Times to the Thirteenth Century. (Translated from Chinese by Burton Watson) New York: Columbia University Press.

Chaves, Jonathan, ed. (1986a): The Columbia Book of Later Chinese Poetry: Yüan, Ming, and Ch'ing dynasties (1279-1911). (Translated from Chinese by Jonathan Chaves) New York: Columbia University Press.

Young, David, ed. (1990a): Five T'ang Poets: Wang Wei, Li Bo, Du Fu, Li He, Li Shangyin. (Translated from Chinese by David Young) Ohio: Oberlin College Press.

Xu, Yuan Zhong, ed. (1994): Songs of the Immortals: An Anthology of Classical Chinese Poetry. (Translated from Chinese by Yuan Zhong Xu) London/New York: Penguin Books.

Weinberger, Eliot, ed. (2003a): The New Directions Anthology of Classical Chinese Poetry. (Translated from Chinese by William Carlos Williams, Ezra Pound, Kenneth Rexroth, et al.) New York: New Directions. 
Barnstone, Tony and Chou, Ping, eds. (2005): The Anchor Book of Chinese Poetry: From Ancient to Contemporary. The Full 3000 Year Tradition. (Translated from Chinese by Tony BARNstone and Ping Chou, with supplements from Willis Barnstone, Arthur Waley, Sam Hamill, et al.) New York: Anchor Books.

Hinton, David, ed. (2008a): Classical Chinese Poetry: An Anthology. (Translated from Chinese by David Hinton) New York: Farrar, Straus \& Giroux.

CaI, Zong-qi, ed. (2008): How to Read Chinese Poetry: A Guided Anthology. (Translated from Chinese by Zong-qi CaI, David Hawkes, Robert Ashmore, et al.) New York: Columbia University Press.

Fuller, Michael A., ed. (2018a): An Introduction to Chinese Poetry: From the Canon of Poetry to the Lyrics of the Song Dynasty. (Translated by the Michael A. Fuller, Stephen Owen, Burton Watson, et al.) Cambridge: Harvard University Asia Center Press.

\section{Appendix 2: Paratexts from the corpus of anthologies}

Barnstone, Tony (2005b): A Note on the Selections and Some Words of Thanks. In: Tony Barnstone and Ping Chou, eds. The Anchor Book of Chinese Poetry: From Ancient to Contemporary. The Full 3000 Year Tradition. (Translated from Chinese by Tony BARnstone and Ping Chou, with supplements from Willis Barnstone, Arthur Waley, Sam Hamill, et al.) New York: Anchor Books, xxxv-xxxvii.

Chaves, Jonathan (1986b): Introduction. In: Jonathan Chaves, ed. The Columbia Book of Later Chinese Poetry: Yüan, Ming, and Ch'ing Dynasties (1279-1911). (Translated from Chinese by Jonathan Chaves) New York: Columbia University Press, 1-12.

Cranmer-Byng, Launcelot Alfred (1909b): Introduction. In: Launcelot Alfred Cranmer-Byng, ed. A Lute of Jade: Being Selections from the Classical Poets of China. London: John Murray, 9-28.

FAnG, Achilles (1954): Introduction. In: Ezra Pound, ed. The Confucian Odes. (Translated from Chinese by Ezra Pound) New York: New Direction Paperbook, i-xiv.

Fletcher, William J. B. (1919b): Introduction. In: William J. B. Fletcher, ed. Gems of Chinese Verse. (Translated from Chinese by William J. B Fletcher) Shanghai: The Commercial Press, i-iii.

Fuller, Michael A. (2018b): Author's Note. In: Michael A. Fuller, ed. An Introduction to Chinese Poetry: From the Canon of Poetry to the Lyrics of the Song Dynasty. (Translated by the Michael A. Fuller, Stephen Owen, Burton Watson, et al.) Cambridge: Harvard University Asia Center Press, ix-xi.

Giles, Herbert (1884b): Preface. In: Herbert GiLes, ed. Gems of Chinese Literature. (Translated from Chinese by Herbert GILEs) London/Shanghai: Bernard Quaritch/Kelly \& Walsh, iii-vi.

Hart, Henry (1938b): Introduction. In: Henry HarT, ed. A Garden of Peonies. (Translated from Chinese by Henry НАRт) Stanford/London: Stanford University/Oxford University Press, xi-xiii.

Hinton, David (2008b): Introduction. In: David Hinton, ed. Classical Chinese Poetry: An Anthology. (Translated from Chinese by David Hinton) New York: Farrar, Straus \& Giroux, xix-xxvi.

Jenyns, Soame (1940b): Foreword. In: Soame Jenyns, ed. Selections from the Three Hundred Poems of the T'ang Dynasty. (Translated from Chinese by Soame Jenyns) London: John Murray, 9-22.

Payne, Robert (1947b): Method of Translation. In: Robert Payne, ed. The White Pony: An Anthology of Chinese Poetry from the Earliest Times to the Present Day. (Translated from Chinese by Robert Payne, Yu-ting Shen, Yeh-tzu Yang, et al.) New York: The John Day Company, i-xx.

Rexroth, Kenneth (1956b): Introduction. In: Kenneth Rexroth, ed. One Hundred Poems from the Chinese. (Translated from Chinese by Kenneth Reхrotн) New York: New Directions, xi-xii. 
Smith, John (1969): Foreword. In: Duncan MacKintosh and Alan Ayling, eds. A Further Collection of Chinese Lyrics and Other Poems. (Translated from Chinese by Duncan MAcKIntosh, in collaboration with Hsi CH'eng and Ping-cheng T'UNG, and rendered into verse by Alan Ayling) London/New York: Routledge/Kegan Paul, ix-xxii.

WALEY, Arthur (1919c): Introduction. In: Arthur WALEY, ed. More Translations from the Chinese. (Translated from Chinese by Arthur Waley) New York: Alfred A. Knopf, 5-6.

Waley, Arthur (1919d): Preliminary Note. In: Arthur Waley, ed. A Hundred and Seventy Chinese Poems. (Translated from Chinese by Arthur Waley) New York: Alfred A. Knopf, v-vi.

Weinberger, Eliot (2003b): Introduction. In: Eliot Weinberger, ed. The New Directions Anthology of Classical Chinese Poetry. (Translated from Chinese by William Carlos Williams, Ezra Pound, Kenneth Rexroth, et al.) New York: New Directions, xvii-xxvii.

Wolfe, Humbert (1920): [Untitled]. In: Arthur Waley, ed. Poems from the Chinese. (Translated from Chinese by Arthur WaLEY) London: E. Benn, iii.

Young, David (1990b): Preface. In: David Young, ed. Five T'ang Poets: Wang Wei, Li Bo, Du Fu, $\mathrm{Li} \mathrm{He}$, Li Shangyin. (Translated from Chinese by David Young) Ohio: Oberlin College Press, 9-13.

\section{Appendix 3: Other anthologies and paratexts}

Enzensberger, Hans Magnus, ed. (1960): Museum der modernen Poesie [Museum of modern poetry]. (Translated from Chinese by Hans Magnus Enzensberger) Berlin: DescriptionSuhrkamp.

Gautier, Judith, ed. (1867): Le Livre de Jade. (Translated from Chinese by Judith Gautier) Paris: Alphonse Lemerre.

HART, Henry, ed. (1931): A Chinese Market: Lyrics from the Chinese in English Verse. (Translated from Chinese by Henry HarT) Beijing: The French Bookstore.

Hart, Henry, ed. (1933): A Hundred Names. (Translated from Chinese by Henry HarT) Berkeley: University of California Press.

Hart, Henry, ed. (1974): The Charcoal Burner and Other Poems. (Translated from Chinese by Henry HART) Norman: University of Oklahoma Press.

Hawkes, David, ed. (1959): Ch'u Tz'u: Songs of the South. (Translated from Chinese by David Hawkes) Oxford: Clarendon Press.

Hawkes, David, ed. (1959/1985): The Songs of the South. $2^{\text {nd }}$ ed. (Translated from Chinese by David Hawkes) Harmondsworth: Penguin.

Hinton, David, ed. (2004): The Mountain Poems of Meng Hao-jan. (Translated from Chinese by David Hinton) New York: Archipelago Books.

Legge, James, ed. (1876): The Chinese Classics. (Translated from Chinese by James LEgGE) Vol. 4. The She King, or The Book of Poetry. London: Trübner \& Company.

Liu, Wu-Chi and Lo, Irving Yucheng, eds. (1976): 葵猫集 (K’uei Yeh Chi) [Sunflower Splendor]. Bloomington/London: Indiana University Press.

Minford, John and Lau, Joseph S. M., eds. (2000): Classical Chinese Literature: An Anthology of Translations from Antiquity to the Tang Dynasty (Translated by Herbert GiLEs, Stephen Owen, Hsin C. Chang, et al.) Hong Kong: The Chinese University Press.

WAng, Feng and MA, Yan, eds. (2011): A Critical Anthology of Tang Poems and their English Translations. (Translated from Chinese by Feng WANG and Yan MA) Xi'an: Shaanxi People's Publishing Press.

Waley, Arthur, ed. (1946a): Chinese Poems, Selected from 170 Chinese Poems, More Translations from the Chinese, The Temple and The Book of Songs. (Translated from Chinese by Arthur WALEY) London: George Allen and Unwin.

Waley, Arthur, ed. (1946b): Preface. In: Arthur Waley, ed. Chinese Poems, Selected from 170 Chinese Poems, More Translations from the Chinese, The Temple and The Book of Songs. (Translated from Chinese by Arthur WALEY) London: George Allen and Unwin, 5-6. 